\title{
В.А. Печерский
}

\section{ДЕЯТЕЛЬНОСТЬ КРАСНОЯРСКОЙ ЮРИДИЧЕСКОЙ ШКОЛЫ В 1937-1941 гГ.}

\begin{abstract}
Рассматриваются вопросы, связанные с формированием и деятельностью Красноярской юридической школы в 19371941 гг. Учебное заведение было основано по решению крайкома ВКП(б) для подготовки кадров органов юстиции. В первый год своего функционирования школа испытывала большие трудности с помещением для занятий, что едва не привело к её закрытию. Основу преподавательского коллектива школы составляли сотрудники судебных и прокурорских органов Красноярского края, которые совмещали основную работу с педагогической деятельностью. В довоенный период школа выпустила 124 дипломированных юриста, степень подготовки которых была на достаточно низком уровне.

Ключевые слова: Красноярский край; Красноярская юридическая школа; юридическое образование в СССР; органы юстиции.
\end{abstract}

К середине 1930-х гг. уровень подготовки работников советской юстиции оставлял желать лучшего. Многие судьи, прокуроры, следователи не имели юридического образования, что сказывалось на качестве отправления правосудия. В руководстве страны получила поддержку идея расширения профессиональной подготовки сотрудников судебных и прокурорских органов.

Для быстрой и эффективной учёбы будущих юристов в СССР была создана сеть юридических школ с одногодичным сроком обучения. Всего в стране в первой половине 1930-х гг. были созданы 44 юридические школы, из которых 29 находились на территории РСФСР [1. С. 83]. Среднее юридическое образование в СССР в 1930-е гг. получило освещение в работах А.Я. Кодинцева и П. Соломона [1-3]. В трудах названных историков даётся общий обзор среднего юридического образования, работа же отдельных учебных заведений изучена недостаточно.

В данной статье впервые исследуется деятельность Красноярской юридической школы по подготовке кадров юстиции от момента её организации в 1937 г. до начала Великой Отечественной войны.

Постановление об образовании правовой школы в Красноярске было принято Президиумом Красноярского крайисполкома 16 января 1937 г. Начать работу школы предполагалось 1 марта 1937 г. Ей выделялось здание краевого отдела здравоохранения, который в свою очередь планировалось перевести в здание крайисполкома [4. Л. 58].

Планы краевых властей оказались под угрозой срыва из-за ряда обстоятельств. Прежде всего, возникли проблемы с помещением, крайздравотдел не освободил переданное под школу здание, и 23 мая 1937 г. крайисполком своим постановлением передал для школы рубленый барак на участке «Мужичкино» Красноярской железной дороги площадью 300 квадратных метров в 37 км от Красноярска. На перевозку и оборудование помещения было выделено 30 тыс. руб., однако при расчёте всех расходов на эти мероприятия выяснилось, что требовалось 50557 руб. 75 коп. [4. Л. 100]. Такие затраты не позволили перевезти барак в краевой центр, и школа осталась без помещения.

Председатель краевого суда Я.Ф. Королёв был вынужден арендовать у Лесотехнического института две аудитории с оплатой по 700 руб. в месяц за каждую и две комнаты в общежитии на 35 человек с оплатой по
2 руб. в день с человека на срок с 1 июля по 15 августа 1937 г. [4. Л. 68]. Правовая школа нашла лишь временное пристанище, с началом занятий в Лесотехническом институте школа должна была освободить помещения.

У нового учебного заведения отсутствовало и общежитие. Поэтому иногородних курсантов в количестве 40 человек по решению крайисполкома предполагалось разместить в «Доме колхозника», отдельно от других, проживавших там [Там же. Л. 19]. Изолировать учащихся от других постояльцев «Дома колхозника» было решено для того, чтобы другие постояльцы не мешали курсантам заниматься и отдыхать.

Другой проблемой, возникшей при организации школы, было комплектование состава учащихся. Набирать курсантов было решено двумя путями. Первый - подбор на местах. Краевой суд отдал распоряжение местным судебным органам о подборе и направлении абитуриентов в правовую школу. Некоторые судебные работники недостаточно серьёзно отнеслись к этому заданию. Так, председателю Хакасского областного суда Ф.С. Толстухину было поручено отобрать 15 человек для направления на экзамены в школу, но областной суд, несмотря на неоднократные напоминания, к 22 мая 1937 г. не выслал материалы ни на одного абитуриента. Председателю краевого суда и директору школы пришлось обратиться к секретарю Хакасского обкома ВКП(б) [Там же. Л. 18].

Второй путь комплектования - свободный набор. В номере газеты «Красноярский рабочий» от 15 марта 1937 г. было помещено объявление от имени краевого суда, информировавшее о наборе учащихся в правовую школу. Подать заявление о приёме имели право мужчины и женщины в возрасте от 22 до 40 лет, имевшие образование не ниже 7 классов средней школы. Желавшие стать курсантами должны были представить в приёмную комиссию следующие документы: о рождении и отношении к воинской службе, заверенную автобиографию, отзыв с места последней работы, отзыв партийной (если член ВКП(б)), комсомольской (если член ВЛКСМ) или профессиональной (если беспартийный) организации [5]. В только что организованное, малоизвестное учебное заведение абитуриенты не спешили нести свои документы. Здесь сказывался и возрастной ценз для поступавших. Взрослые люди зачастую не стремились менять профессию и, соответственно, отказываться от привычного образа жизни. 
Крайне негативно на организацию работы школы повлияло и отсутствие постоянного преподавательского состава. Для школы не нашлось даже освобождённой должности директора. Руководить учебным заведением было поручено начальнику отдела кадров краевого суда А. Соколову. Своё назначение он воспринял отрицательно, заявив в докладной записке в наркомат юстиции РСФСР и крайком: «Я считаю совершенно невозможным быть начальником отдела кадров крайсуда и директором школы, при таком совмещении я работу обеспечить ни по кадрам, ни по школе не могу» [4. Л. 113].

К проблеме нехватки преподавателей добавлялось отсутствие программ и учебников. Многие программы и учебные пособия по правовым дисциплинам были созданы на основе трудов бывшего заместителя наркома юстиции СССР Е.Б. Пашуканиса, который 20 января 1937 г. был арестован как «враг народа». Программы и учебники спешно пересматривались, вскрывались «антипартийные, антиленинские положения». К 22 мая 1937 г. школа не получила программы по таким предметам, как государственное устройство и Конституция СССР, уголовное право и исправительно-трудовая политика, гражданское право, земельно-колхозное право, трудовое право, гражданский процесс, история ВКП(б) и Коминтерна [Там же. Л. 20]. Даже несмотря на отсутствие программ по основополагающим правовым дисциплинам, руководители школы не могли использовать программы и учебные пособия за прошлые годы, в противном случае они рисковали оказаться на скамье подсудимых.

Перечисленные выше трудности были вызваны тем, что школа создавалась фактически на пустом месте. В стране в 1930-е гг. были очень слабые традиции подготовки юристов, а в Красноярском крае таковые вовсе отсутствовали.

Проблемы с помещением, педагогическим персоналом, программами и учебными пособиями привели к тому, что приступить к занятиям Красноярская правовая школа смогла только 15 июня 1937 г. При этом из-за нехватки помещений, учебников и программ систематически срывались занятия, допускались отступления от учебного плана в последовательности преподавания юридических дисциплин. Фактически не велось преподавание курсов трудового и земельноколхозного права.

Вследствие нехватки мест в общежитиях и слабой вербовочной политики вместо намеченных по плану 60 слушателей в школу было набрано лишь 37 человек. Пребывавшие в тяжёлых бытовых условиях иногородние курсанты были предоставлены сами себе, новый директор школы Феоктистова была загружена хозяйственными делами и не занималась не только планированием учебного процесса, но и воспитательной работой. Учебным процессом руководила секретарь школы - «дочь расстрелянного врага народа». В результате среди учащихся наблюдались большой процент отсева, низкий уровень дисциплины. Курсанты плохо усваивали изучаемый материал. Следствием невнимания к проблемам слушателей было самоубийство курсанта-эвенка Дуракова. Поло- жение в школе заставило председателя краевого суда издать в апреле 1939 г. приказ о снятии Феоктистовой с должности [6. Л. 1].

Вопросы, возникшие при организации школы, не были разрешены во время первого учебного года. Они носили объективный характер, являлись следствием дефицита жилых и служебных помещений в Красноярске, нехватки квалифицированных педагогов и политических репрессий, в самый пик которых организовывалось учебное заведение. На этом фоне вина директора выглядела довольно сомнительно.

Такое положение едва не привело к закрытию школы. Нарком юстиции РСФСР Я.П. Дмитриев своим телеграфным распоряжением от 29 июля 1938 г. в связи с необеспеченностью помещением и преподавателями предложил к 1 сентября 1938 г. закрыть Красноярскую школу, несмотря на то что уже был объявлен набор на следующий учебный год. Крайком и руководство краевого суда не согласились с этим предложением, наркому сообщили, что под школу был занят третий этаж площадью 180 квадратных метров в новом здании, что обеспечивало размещение 50 учащихся. Школу удалось отстоять, и 3 августа 1938 г. было получено разрешение о наборе 50 человек на новый учебный год [Там же. Л. 3]. Необходимость подготовки юристов заставила крайком и краевой суд бороться за сохранение правовой школы, несмотря на то что последняя оказалась весьма проблемной затеей.

Претензии у наркома были не только к Красноярской школе. В своём приказе от 24 января 1938 г. Я.П. Дмитриев отмечал: «Высокие требования, предъявляемые Сталинской Конституцией к работникам суда, прокуратуры и следствия, с одной стороны, и недостаток юридических кадров, ощущаемый особенно остро в настоящее время, с другой, требуют от руководства органов суда и прокуратуры максимального развёртывания и укрепления действующей сети правовых школ и юридических курсов». Нарком заметил, что «существующая сеть юридических институтов не обеспечивает подготовки потребного количества работников, и на ближайшие 3-4 года основным источником пополнения кадров юстиции будут правовые школы». В связи с этим нарком указывал председателям судов и прокурорам краёв, областей и АССР на недооценку работы по организации правовых школ. Среди недостатков он обозначил «засорённость» ряда школ «враждебными и политическими ненадёжными людьми», к таковым учебным заведениям относились школы Пятигорска, Кирова и Куйбышева. В подобном состоянии дел Я.П. Дмитриев обвинял председателей судов и прокуроров этих областей, «самоустранившихся» от руководства школами [7. Л. 1]. Внимание республиканского наркомата юстиции было направлено прежде всего на подбор «правильных» курсантов для школ. Это соответствовало духу времени, государство взяло курс на репрессивную политику, а Я.П. Дмитриев был одним из её проводников.

Однако повседневные трудности средних учебных заведений заставили наркома обратить внимание и на них. В приказе от 28 августа 1938 г. он отметил сле- 
дующие недостатки, «снижающие качество работы правовых школ»: низкое качество теоретической подготовки учащихся, особенно по специальным дисциплинам; необеспеченность школ квалифицированными преподавателями; отсутствие надлежащей организационно-методической работы и недостаточный контроль за преподавателями; отсутствие должной дисциплины среди учащихся и преподавателей; необеспеченность ряда школ специально приспособленными и оборудованными учебными помещениями и общежитиями [7. Л. 8]. Указав на недостатки в работе школ, нарком не предложил способов их преодоления, и руководству местных органов юстиции приходилось справляться с ними самостоятельно.

Первый учебный год в Красноярской юридической школе закончился экзаменами по уголовному праву и уголовному процессу и гражданскому праву и гражданскому процессу. Из 32 курсантов, допущенных к экзаменам, сдали все дисциплины 29. По окончании экзаменов учащиеся были направлены на производственную практику в судебные и прокурорские органы Красноярска и Хакасской автономной области. После практики аттестационная комиссия распределила выпускников следующим образом: на судебную работу - 13 человек, в прокуратуру - 11, в адвокатуру -4 , в нотариат -1 [6. Л. 2-3].

Подготовив первую группу специалистов для органов юстиции края, школа начала новый набор. 1 июня 1938 г. газета «Красноярский рабочий» опубликовала объявление о наборе в школу. В отличие от предыдущего года, набор объявлялся не от имени краевого суда, а от имени самой школы, именовавшейся уже не правовой, а юридической [8]. Также руководство краевого суда и краевой прокуратуры дали указание народным судьям и районным прокурорам о командировании в школу «лиц из числа правового актива, отвечающих требованиям приёма». Крайком установил для каждого района определённое количество мест в юридической школе и обязал районные партийные организации отчитываться в выполнении данного распоряжения.

Уже к 1 августа 1938 г. было подано 270 заявлений о приёме в школу. Все заявления рассматривались отборочной комиссией в составе директора школы, представителя краевого суда и представителя краевой прокуратуры. Закончив свою работу 10 августа 1938 г., комиссия допустила до приёмных испытаний 220 человек. На испытания, проходившие с 15 по 25 августа 1938 г., прибыли 132 человека, которых на время экзаменов обеспечили местами в общежитии. Из отдельных районов абитуриенты не смогли приехать вовремя, поскольку не получили вызов своевременно, причиной этого было упомянутое выше распоряжение наркома юстиции о закрытии школы. Испытания состояли из экзаменов по русскому языку, математике и политической грамоте в объёме семилетней школы.

По окончании приёмных испытаний вопрос о зачислении рассматривался приёмной комиссией в составе директора школы, председателя краевого суда и представителя краевой прокуратуры и окончательно решался директором школы. По результатам испыта- ний в школу были зачислены 50 человек, из них в возрасте 18-25 лет - 43, свыше 25 лет - 7. Образование до 5 классов имели 4 новых курсанта, 7 классов 34, свыше 7 классов - 12. В органах юстиции до приёма в школу работали 10 человек, в советских, партийных и комсомольских организациях - 30, на производстве -4 , учились - 6. Среди курсантов не было ни одного члена ВКП(б), 9 являлись кандидатами в члены партии, 35 - комсомольцами, 6 - беспартийными [6. Л. 3a-4].

К началу своего второго учебного года школа обрела популярность среди населения края. В 1938 г. конкурс при поступлении составлял 4,4 человека на место. Это было связано прежде всего с тем, что был снижен до 18 лет предельный возраст для абитуриентов. Подавать заявления на поступление стали молодые люди, недавно окончившие семилетнюю школу и стремившиеся получить профессию, они и составляли основу контингента учащихся. Невыполнение разнарядки по подбору кандидатур для обучения в юридической школе местными судами и прокуратурами привело к отсутствию среди студентов членов партии. Зачастую члены ВКП(б), отобранные для поступления, задерживались местными партийными органами для работы в районах и городах. Ввести партийных в состав контингента учащихся не помогло и то, что для них делалось исключение в правилах приёма: от них не требовались наличие семиклассного образования и успешное прохождение приёмных испытаний.

Занятия в 1938/1939 учебном году начались 1 сентября 1938 г. В составе педагогического коллектива были преподаватели русского языка, математики, истории СССР, истории ВКП(б), уголовного права, уголовного процесса, гражданского права, гражданского процесса, судоустройства, криминалистики, трудового права, судебной медицины и психиатрии. Обеспечить школу педагогическими кадрами помогло постановление бюро крайкома, обязывавшее председателя краевого суда и краевого прокурора направить в школу преподавателей по юридическим дисциплинам из числа практических работников суда и прокуратуры.

Отсутствие учебников по ряду дисциплин и неудовлетворительное качество самостоятельной работы курсантов спровоцировали низкую успеваемость в первый месяц нового учебного года. За сентябрь 1938 г. 6\% всех оценок были «отлично», 37,4\% - «хорошо», $36,6 \%$ - «удовлетворительно», 12,6\% - «неудовлетворительно», 7,4\% курсантов были вовсе не оценены. Для улучшения успеваемости все курсанты заключили между собой договор о социалистическом соревновании за лучшее качество учёбы. Чтобы помочь отстававшим, были организованы дополнительные консультации по математике. По инициативе школьного комитета ВЛКСМ успевавшие курсанты были прикреплены к отстававшим. При школе работали кружки по изучению законодательства. Эти меры не замедлили дать положительный результат, в октябре 1938 г. оценки «отлично» составляли уже $11,8 \%$, хорошо - 45,4\%, «удовлетворительно» - 34,8\%, «неудовлетворительно» - 4,8\%, не оценены были 3,2\% курсантов [Там же. Л. 5-6а]. 
Таким образом, в начале второго учебного года юридическая школа сумела решить большинство проблем периода становления. Появились помещения для занятий и проживания курсантов, имелись программы и учебные пособия по большинству профилирующих дисциплин. Руководство Красноярского края оказывало школе всю возможную помощь.

По плану в 1938/1939 учебном году в школе должны были пройти занятия в объёме 1380 учебных часов, фактическое выполнение учебного плана составляло 1372 часа. По итогам года по всем дисциплинам отличные оценки получили $33 \%$ учащихся, «хорошо»47\%, «удовлетворительно» - 19,9\%, «неудовлетворительно» - 0,1\% [6. Л. 28]. Недовыполнение учебного плана, составлявшее 8 часов, было незначительным, что свидетельствовало об умелой организации учебного процесса. Уровень успеваемости курсантов продолжал оставаться на достаточно высоком уровне.

К концу 1938/1939 учебного года из состава учащихся отсеялись 5 человек, и к 1 августа 1939 г. в школе обучались 45 курсантов. Государственный экзамен по уголовному праву сдали все учащиеся, из них на «отлично» - 51\%, «хорошо» - 40\%, «удовлетворительно» - 9\%. Курсант Шестаков сразу после сдачи этого экзамена был призван на военный сбор, и ему была предоставлена отсрочка по сдаче остальных государственных экзаменов, поэтому последующие испытания сдавали 44 из 45 курсантов. Гражданское право сдали 43 учащихся, из которых «отлично» получили $42,3 \%$, «хорошо» - 39,2\%, «удовлетворительно» - 16,3\%, «неудовлетворительно» - 2,2\%. Экзамен по уголовному процессу сдали 44 курсанта, 30\% - на «отлично», 43\% - на «хорошо», 27\% - на «удовлетворительно». Гражданский процесс из 44 учащихся на отличную оценку сдали $39 \%$ курсантов, «хорошо» 40\%, «удовлетворительно» - 21\% [Там же. Л. 28-29].

Более успешно курсанты сдали экзамен по уголовному праву, только оценку «отлично» по этому предмету получили свыше половины экзаменуемых. Куда менее благополучно проходили экзамены по другим дисциплинам, прежде всего по гражданскому праву. Обучение советских юристов ориентировалось прежде всего на подготовку специалистов уголовноправовой направленности. Соответственно, этому предмету уделялось наибольшее внимание.

Решением аттестационной комиссии выпускники 1939 г. распределялись следующим образом: в органы прокуратуры - 13 человек, в народные судьи - 16, членами краевого или областного суда -2 , членами коллегии защитников -7 , нотариальными работниками - 5. Не аттестованы были 2 выпускника.

Акт комиссии противоречил желанию некоторых молодых юристов, которые категорически отказались подчиняться решению о распределении и подали заявление в прокуратуру о приёме на работу следователями. Так, в прокурорские органы перешли Юдин из нотариата, Матюхина из членов Хакасского областного суда, Кулешов и Турчанов из коллегии защитников. Даже неаттестованные курсанты Саксин и Торгашина были определены следователями в прокурорские органы. Образовавшиеся в результате самоволь- ства ряда выпускников свободные вакансии в некоторых органах юстиции пришлось заполнять за счёт других организаций: получившая распределение в прокуратуру Краснопёрова была переведена в краевой суд, а назначенные народными судьями Оленпинченко и Моисеев перешли в коллегию защитников [6. Л. 28].

Комиссия по распределению не учитывала желания выпускников, часто их просто ставили перед фактом, лишая свободы выбора места работы. Однако те, кто не желал следовать решению комиссии, мог этого не делать без особых для себя последствий. Наиболее популярным местом работы для дипломированных юристов были прокурорские органы, поскольку образ следователя прокуратуры был идеализирован не только литературой и кино, но и прессой, представлявшей следователей беспощадными борцами с «врагами народа».

В итоге выпускники 1939 г. распределились следующим образом: в прокурорские органы - 19 человек, или 42,3\%, в народные судьи - 13 (28,8\%), в коллегию защитников - 9 (20\%), в нотариальные работники - 4, или 8,9\% [Там же. Л. 31].

Объём знаний выпускников юридических школ не соответствовал запросам органов юстиции. Качество работы выпускников этих учебных заведений показывало, что за один учебный год они не успевали освоить весь необходимый объём знаний и стать полноценными специалистами. Для преодоления этих недостатков необходимо было увеличить срок обучения.

Приказом наркома юстиции СССР от 11 мая 1939 г. «О переводе правовых школ на двухгодичный срок обучения» часть учащихся, принимаемых в 1939 г., зачислялись на одногодичный срок обучения, а другая часть - на двухгодичный. Предусматривалось, что в 1939/1940 учебном году состоится последний выпуск слушателей с одногодичным сроком обучения, и последующие потоки будут обучаться исключительно по 2 года [9. Л. 1]. Переход к двухгодичному обучению осуществлялся планомерно, и поначалу в школах должны были параллельно учиться курсанты с различным сроком обучения.

Подготовка школы к новому учебному году началась с объявления о наборе учащихся в краевой газете [10]. Это объявление было также прочитано по радио. В связи с приказом наркома 18 июля 1939 г. в «Красноярском рабочем» было опубликовано новое объявление о наборе на одногодичное и двухгодичное обучение [11]. Вместе с этим крайком ВКП(б) дал указание райкомам об отборе для поступления в школу представителей партийно-комсомольского актива [6. Л. 31].

По плану предполагалось набрать 60 человек: 30 на одногодичный срок обучения и 30 - на двухгодичный. На 1 августа 1939 г. в приёмную комиссию поступило 345 заявлений, к приёмным испытаниям был допущен 121 человек, из которых членов и кандидатов ВКП(б) было 9, комсомольцев - 92, беспартийных - 20. Образование 7 классов имели 92 абитуриента, свыше 7 классов - 29 [Там же].

Краевое руководство, несмотря на то что количество заявлений от желавших стать курсантами школы было достаточным для набора учащихся на новый учебный год, по-прежнему требовало от местных пар- 
тийных органов подбирать для школы коммунистов и комсомольцев. Поскольку крайком был заинтересован в политической лояльности будущих работников юстиции не меньше, чем в их профессионализме, этому вопросу уделялось большое внимание.

К началу нового учебного года учебный корпус, располагавшийся в Красноярске по адресу улица Кирова, 33, был отремонтирован, и в нём вполне комфортно могли проходить обучение 60 человек, общежитие же могло принять лишь 35 учащихся. Поскольку большинство курсантов были иногородними, возможности общежития не соответствовали потребностям школы. Для обеспечения остальных учащихся жилплощадью школа дала объявления в газету и на радио о снятии комнат. Некоторые жители краевого центра предлагали сдать жильё за 60-70 руб. в месяц на человека, тогда как школа имела возможность платить не более 45 руб.

Другой проблемой была нехватка учебников. На 1 августа 1939 г. в школьной библиотеке имелось 20 учебников по общей части уголовного права, 18 по советскому уголовному праву, 40 - по первой части и 40 - по второй части гражданского права, 60 по гражданскому процессу, 33 - по трудовому праву, 65 - по колхозному праву, 20 - по истории ВКП(б) [6. Л. 31-32]. Поскольку в 1939/1940 учебном году курсанты занимались по разным программам, дефицит учебных пособий усугублялся необходимостью делить их между разными потоками.

К преподаванию в новом учебном году были привлечены 11 человек. Из них лишь один являлся штатным работником школы, это был директор Н.К. Назаренко. Николай Кузьмич родился в 1908 г., был членом ВКП(б) с 1927 г. Его общее образование ограничивалось тремя классами, но он закончил Свердловский юридический институт. В школе Н.К. Назаренко преподавал гражданское право и гражданский процесс.

Все прочие преподаватели являлись сотрудниками судебных и прокурорских органов и работали в школе по совместительству. Большинство из них закончили различные юридические вузы. Так, Свердловский институт, помимо директора школы, окончил преподаватель трудового права В.Л. Кожевников 1900 года рождения, по основной должности народный судья. Выпускником Саратовского юридического института был член краевого суда С.И. Грицов, преподаватель уголовного права. Дипломы Московского юридического института имели помощник краевого прокурора Ф.М. Базыкин (уголовный процесс) и красноярский городской прокурор И.Ф. Давыдов (колхозное право). Другой преподаватель уголовного процесса - помощник краевого прокурора П.Г. Денисенко - окончил Иркутский юридический институт. Заместитель краевого прокурора по спецделам В.Н. Букланов (Конституция СССР) был выпускником Института советского права Ленинградского университета.

Юридическое образование других преподавателей ограничивалось курсами. Шестимесячные курсы окончили заместитель краевого прокурора П.С. Ковалёв (история ВКП(б)) и председатель краевого суда Н.А. Лебедев (судоустройство СССР). Выпускником одногодичных юридических курсов был заместитель председателя краевого суда Г.Н. Краснопёров (судебная статистика). Старший лейтенант милиции М.Д. Титаренко (криминалистика) вовсе не имел юридического образования. Из 11 преподавателей 9 были членами ВКП(б), 1 - комсомольцем (С.И. Грицов), 1- беспартийным (П.Г. Денисенко) [6. Л. 34].

Часть преподавателей имели образование ниже того уровня, которое они давали своим студентам. Уровень теоретической подготовки таких педагогов не соответствовал запросам среднего юридического образования, и им приходилось изучать преподаваемые предметы в процессе подготовки к занятиям. Их практический опыт не мог полностью компенсировать пробелы в юридическом образовании.

Отсутствие постоянного штата преподавателей приводило к тому, что невозможно было составить стабильное расписание, каковое приходилось согласовывать с совместителями, которые, кроме всего прочего, часто уезжали в командировки, не уведомляя об этом директора школы, что приводило к срыву занятий. По этой же причине в школе не работали цикловые комиссии и не проводились заседания педсовета [Там же. Л. 35]. Поскольку при дефиците специалистов любой образованный юрист был востребован органами юстиции, собрать в исследуемый период постоянный штат преподавателей юридической школы не представлялось возможным.

1 сентября 1939 г. к занятиям приступили 66 курсантов, из них 32 в группе с одногодичным сроком обучением, 34 - с двухгодичным. Из учащихся, обучавшихся один год, 5 являлись членами ВКП(б), 25 ВЛКСМ, 2 - беспартийными; 19 окончили 7 классов, $6-8$ классов, $4-9$ классов, 3 - 10 классов. Из курсантов, поступивших на двухгодичное обучение, 2 были членами партии, 28 - комсомольцами, 4 - беспартийными; 6 классов закончили 2 человека, 7 классов - 26, 8 классов $-4,9$ классов $-1,10$ классов -1 . К концу первого семестра, закончившегося 23 января 1940 г., 8 курсантов отсеялись, так как были призваны в РККА [Там же. Л. 36]. Таким образом, среди учащихся по-прежнему преобладала молодёжь.

По приведённым выше причинам в первом семестре 1939/1940 учебного года учебный план не был выполнен. Из намеченных 624 учебных часов для группы с одногодичным сроком обучения фактически было выполнено 607. В группе с двухгодичным сроком обучения из 626 часов фактически было выполнено 622 [Там же. Л. 37].

Незначительное недовыполнение учебного плана не являлось основной проблемой школы. В связи с набором лишних 6 курсантов в первом семестре имела место нехватка учебных помещений, рассчитанных на 60 человек. По частным квартирам приезжих учащихся пришлось размещать в отдалённых от центра частях Красноярска, поскольку в центре хозяева соглашались сдавать комнаты не дешевле, чем за 75 руб. в месяц, а НКЮ РСФСР разрешал платить не более 70 руб. [Там же. Л. 38].

Красноярская юридическая школа к началу 1940 г. миновала стадию становления, преодолев большин- 
ство проблем роста, а возникавшие перед ней вопросы являлись отражением советской действительности 1930-х гг. с её идеологическими установками и постоянным дефицитом товаров и услуг. Данные вопросы разрешались благодаря помощи крайкома и наркомата юстиции и расторопности руководства школы.

30 июля 1940 г. состоялся последний выпуск курсантов, обучавшихся по программе одногодичной школы было выпущено 23 человека. В основном это были молодые люди 1918-1921 гг. рождения, однако лучшими выпускниками были В.В. Шукаев 1915 г. рождения и самый возрастной учащийся И.М. Бобров 1909 г. рождения. Директор школы своим приказом «за успешное окончание юридической школы на “отлично”, активную массово-политическую работу, дисциплинированность» премировал Василия Владимировича и Ивана Михайловича деньгами в сумме 125 руб. каждого [12. Л. 38-39].

В 1940/1941 учебном году на первый курс школы планировалось набрать 30 человек. Набор осуществлялся традиционными путями. Было дано объявление в краевой газете о наборе в Красноярскую юридическую школу со сроком обучения 2 года лиц в возрасте от 18 до 40 лет, имевших образование 7 классов. На вступительных испытаниях от абитуриентов требовалось продемонстрировать знания по Конституции СССР, истории народов СССР, русскому языку. Без приёмных экзаменов принимались выпускники десятилетки и те, кто окончил рабфак на «отлично» [13]. Объявление было также прочитано по радио.

Крайком специальным письмом требовал от райкомов подобрать кандидатуры для поступления в школу, то же самое управление НКЮ и краевая прокуратура приказывали сделать народным судам и районным прокуратурам. К 11 августа 1940 г. было подано 259 заявлений на поступление, к вступительным испытаниям были допущены 59 человек, из них 7 были членами партии, 46 - комсомольцами, 6 - беспартийными. Большинство из абитуриентов, подавших заявление, были молодыми людьми 19201923 гг. рождения, окончившими семилетку.

По указанию Управления учебными заведениями НКЮ РСФСР директор школы вернул заявления абитуриентам 1919-1922 гг. рождения, предложив им представить справки медицинских комиссий при райвоенкоматах. Большинство из них не подавали заявлений вторично, поэтому из допущенных к испытаниям 59 абитуриентов 42 (71\%) были женщины, что и определило будущий состав учащихся [14. Л. 8].

Это требование было связано с принятием Закона о всеобщей воинской обязанности, вступившего в силу 1 сентября 1939 г., согласно которому призыву в армию подлежали все мужчины - граждане СССР, не имевшие среднего образования, с 19 лет, а окончившие среднюю школу и «ей соответствующие учебные заведения» - с 18 лет. Все зачисленные в школу молодые мужчины подлежали бы воинскому призыву.

В школу поступили 34 человека, из них 1 был членом ВКП(б), 4 - кандидатами в члены партии, 27 состояли в ВЛКСМ, 2 являлись беспартийными. 7 классов окончил 21 курсант, 8 классов - 7, 9 клас- сов - 3, 10 классов - 3. 12 были мужчинами, 22 женщинами. В возрасте до 20 лет были 20 первокурсников, до 30 - 13, старше $30-1$. До поступления в школу 9 курсантов набора 1940 г. обучались в других учебных заведениях, 19 работали советских, профсоюзных или хозяйственных организациях, 1 служил в армии, 2 были домохозяйками, 3 - сотрудниками органов юстиции [14. Л. 1].

Приведённый состав учащихся показывает, что райкомы и местные органы юстиции вновь формально отнеслись к распоряжению краевых властей, и подобранные ими кандидаты не были зачислены в школу, поскольку число коммунистов среди курсантов уменьшилось ещё больше по сравнению с предыдущими наборами. Также работники юстиции не горели желанием повысить свой образовательный уровень. Среди курсантов преобладали молодые люди, сотрудники различных учреждений, желавшие получить юридическое образование из карьерных соображений или желания переменить профессию. Впервые за всё время работы школы большинство курсантов на потоке составляли женщины.

К концу первого полугодия 1941 г. на первом курсе обучались 22 человека, на втором - 26. 10 первокурсников были отчислены по семейным обстоятельствам, 1 призван в армию, 1 исключён «за совершение проступка, порочащего звание учащегося юршколы». Пятеро второкурсников были мобилизованы в РККА, 1 отчислен по семейным обстоятельствам. В виде исключения 10 ноября 1940 г. на второй курс был принят бывший студент Саратовского юридического института, отчисленный оттуда по семейным обстоятельствам [Там же. Л. 1].

Причины отсева явно были связаны с половой структурой различных потоков: семейные обстоятельства заставили покинуть школу большинство отчисленных учащихся первого курса, где основную часть составляли женщины, тогда как на втором курce, где преобладали мужчины, большинство покинувших школу составляли мобилизованные в армию.

В преподавательском составе школы в 1940 г. произошли значительные изменения. Из тех, кто преподавал годом ранее, остались Ф.М. Базыкин, С.И. Грецов, В.Л. Кожевников, И.Ф. Давыдов и директор Н.К. Назаренко. Гражданское право начал преподавать Г.И. Романов, член краевого суда, имевший общее образование 7 классов, юридическое в объёме шестимесячных курсов. Член краевой коллегии адвокатов В.А. Тархов, имевший общее среднее и высшее юридическое образование, читал курс советского государственного права. Курс криминалистики взял на себя новый председатель краевого суда И.В. Анипченко, окончивший полный курс средней школы и юридический институт. Судебную медицину преподавала городской судмедэксперт М.Д. Яковлева, выпускница медицинского института.

Завучем школы была назначена Л.А. Кузнецова. Лидия Андреевна родилась в 1917 г., окончила педагогический техникум и юридический институт. Она вела курс судоустройства СССР.

Высокой квалификацией обладали преподаватели общеобразовательных дисциплин. Высшее образова- 
ние имел географ Красноярского дома партийного просвещения В.И. Соколов, преподававший эту дисциплину в юридической школе. Консультант того же учреждения В.В. Рубцова, также получившая высшее образование, вела историю ВКП(б). Выпускник Московского института философии, литературы и истории В.И. Неупокоев, штатный преподаватель Красноярского педагогического института, вёл курс истории CCCP. Окончивший военную школу пилотов Н.П. Нахабов преподавал военную допризывную подготовку. Преподаватель математики В.В. Евсеева не имела высшего образования, но стаж работы Валентины Васильевны, родившейся в 1895 г., исчислялся с 1906 г. Также только среднее образование было у В.Я. Горишней, учительницы общеобразовательной школы, ведшей курс русского языка [15. Л. 2]. Уровень преподавательского состава в 1940 г. значительно вырос. В педагогическом коллективе школы теперь подавляющее большинство составляли люди с высшим образованием. Однако по-прежнему превалировали совместители, что сказывалось на стабильности расписания.

В 1940 г. в школе был внедрен ряд новшеств. Первым из них было введение платы за обучение. Это было сделано на основании постановления СНК СССР от 26 октября 1940 г. «Об установлении платности обучения в старших классах средних школ и в высших учебных заведениях СССР и об изменении порядка назначения стипендий». В сёлах и провинциальных городах Советского Союза плата за обучение в школах, а также в специальных средних учебных заведениях составляла 150 руб. в год. С этим постановлением был связан перевод школы на вечернее обучение - с 16:00 до 22:00, поскольку часть учащихся были устроены на работу в органы юстиции, чтобы иметь возможность заработать деньги на учёбу. В народных судах в качестве судебных исполнителей и в архивах трудились 15 курсантов, в адвокатуре - 3, в прокуратуре - 3. Для них был установлен шестичасовой рабочий день, зарплата выплачивалась пропорционально рабочему времени. К концу 1 полугодия 1940/1941 учебного года все учащиеся были уволены по сокращению штатов [14. Л. 2]. Население СССР не отличалось высокими доходами, и сумма в 150 руб. в год была достаточно обременительной для большинства курсантов и их родственников.

Желанием привлечь в число учащихся школы действующих работников юстиции, а также военнослужащих было продиктовано появление такого нововведения, как экстернат. В начале 1940/1941 учебного года на эту форму обучения были набраны 29 человек, большинство из которых составляли красноармейцы действительной военной службы. Военные не освобождались от платы за обучение, а для красноармейцев она была слишком высока, и 11 марта 1941 г. все военнослужащие были отчислены из школы. Дальнейшее обучение экстерном продолжали 5 человек, представлявшие следующие профессии: учитель, счетовод, заведующий партийным кабинетом, нотариус и адвокат [9. Л. 41].

Таким образом, экстернат как доступная форма обучения фактически провалился в первый год своего существования в Красноярской юридической школе. Для представителей одной из категорий, для которых он был предназначен, - военнослужащих - экстернат был неподъёмен в финансовом плане, а работники юстиции поступали на заочное обучение неохотно.

Последний довоенный выпуск состоялся в школе 31 мая 1941 г. В тот день приказом директора школы дипломированными юристами стали 27 человек [12. Л. 58-59]. Выпускники 1941 г. были распределены в различные органы юстиции: 5 - на должности следователей различных прокурорских органов, 9 - адвокатами, 9 - народными судьями, 4 - помощниками прокуроров. Как и в прошлые годы, не все из них были согласны с решением комиссии по распределению. Так, П.А. Белянин, назначенный народным судьёй в Боготольский район, пожелал занять должность следователя прокуратуры. Родившийся в 1914 г. Павел Александрович до поступления в школу работал электросварщиком на Красноярском паровозоремонтном заводе, своё желание поменять должность он мотивировал тем, что работа следователя была менее ответственной [15. Л. 18].

Лучшие выпускники получили назначения на должности следователей, судей и прокуроров. Следователем прокуратуры Пировского района была назначена Г.Г. Брюханова. Галина Георгиевна родилась в 1918 г., окончила 10 классов, была членом ВЛКСМ, в прошлом работала счетоводом Енисейского пароходства. Директор школы охарактеризовал её следующим образом: «Принимает активное участие в общественной работе, в школе и в быту ведёт себя хорошо, выдержанный товарищ, с учёбой прекрасно справляется - отличница, стремится попасть на работу в прокуратуру следователем. Может быть использована на любой работе в суде и прокуратуре» [Там же. Л. 22].

Народным судьёй для работы в краевом центре была рекомендована А.А. Офицерова 1920 г. рождения, в прошлом секретарь народного суда: «Грамотный культурный товарищ, хорошо работает самостоятельно, учится хорошо, серьёзно относится ко всем вопросам» [Там же. Л. 22].

На должность народного судьи или прокурора был рекомендован А.Г. Задеря. Антон Герасимович, член ВЛКСМ, 1921 г. рождения, окончивший 8 классов, получил такую лестную характеристику: «Вполне подготовленный товарищ, дисциплинирован, хорошо разбирается в теоретических вопросах, имеет хорошие способности в учёбе, в школе и в быту пользуется авторитетом, отличник, освобождён от платы за обучение, хотя и молодой, а может быть использован на практической работе нарсудьёй или прокурором» [15. Л. 22]. Он был распределён на должность помощника прокурора в Ирбейский район.

Адвокатура и нотариат приобрели менее успешных выпускников. В.Ф. Ермохина, 1920 г. рождения, окончившая 9 классов, «не имеет жизненного опыта, учится посредственно, может быть рекомендована на работе в нотариате или адвокатуре», получила назначение в Минусинск на должность адвоката. Её ровесник Е.М. Кулешов был охарактеризован как «недостаточно исполнительный, не совсем хорошо отно- 
сившийся к порученному делу», он был рекомендован адвокатом [15. Л. 22]. При распределении курсантов и этого выпуска приоритеты властей по отношению к органам юстиции были совершенно ясны.

Всего в 1938-1941 гг. школу окончили 124 человека, из них 97 обучались 1 год, 27 - 2 года.

Многие выпускники школы были уволены из судов и прокуратур; только в 1940 г. за дискредитацию судебных органов и необеспечение работы в Красноярском крае с должностей было снято 15 народных судей [16. Л. 14].

Низкий уровень образования в Красноярской юридической школе объяснялся несколькими причинами. Во-первых, в учебном заведении не сложился педагогический коллектив. Осуществлявшие преподавательскую деятельность практические работники суда и прокуратуры не обладали педагогическими навыками в должной степени, поскольку многие из них работали в школе не более одного учебного года. У них не было необходимого количества времени для подготовки к занятиям и, иной раз, они просто пересказывали учащимся содержание учебника. Нестабилен был и постоянный состав школы - в 1937/1941 гг. сменилось 4 директора, завучи тоже ненадолго задерживались в должности.

Во-вторых, школа испытывала постоянный дефицит учебных пособий. Учебников не хватало для всех курсантов, учебные пособия по правовым дисциплинам быстро устаревали, а новые поступали в школьную библиотеку с опозданием.
В-третьих, обучить квалифицированного юриста за один учебный год не представлялось возможным, объём материала, который должен был знать будущий работник юстиции, невозможно было усвоить за столь короткий срок. Выходом был перевод обучения на двухлетний срок, был поставлен вопрос о переходе юридических школ на трёхлетнее обучение.

В-четвёртых, уровень общего образования у курсантов не всегда позволял им полноценно осваивать юридические дисциплины. Несмотря на то что одним из основных требований к абитуриентам было наличие семиклассного образования, нередко делались исключения для лиц, не сумевших окончить курс семилетней школы, а уровень подготовки даже окончивших 7 классов не всегда соответствовал запросам среднего юридического образования.

Красноярская юридическая школа не была исключением из правил. В 37 юридических школах, бывших в РСФСР в 1940 г., не было постоянных штатов преподавателей и необходимых учебников. Часто отсутствовали стабильные планы и учебные программы [3. С. 264].

Таким образом, Красноярская юридическая школа, являясь частью советской юридической образовательной системы, испытывала те же трудности, что и другие учебные заведения правового профиля. При поддержке краевых властей и наркомата юстиции она могла стать полноценным центром подготовки работников юстиции, однако война помешала реализовать школе свой потенциал.

\section{ЛИТЕРАТУРА}

1. Кодинцев А.Я. Среднее юридическое образование в системе органов юстиции СССР в 30-е годы ХХ века // Среднее профессиональное образование. 2007. № 9. С. 83-84.

2. Кодинцев А.Я. Заочное юридическое образование в системе органов юстиции СССР в 30 -е гг. ХХ века // Научные исследования в образовании. 2007. № 6. С. 74-79.

3. Соломон П. Советская юстиция при Сталине / пер. с англ. М. : РОССПЭН, 1998. 464 с.

4. Государственный архив Красноярского края (далее - ГАКК). Ф. Р-1266. Оп. 1. Д. 1.

5. Красноярский рабочий (Красноярск). 1937. 15 марта.

6. ГАКК. Ф. Р-1266. ОП. 1. Д. 2.

7. ГАКК. Ф. Р-1266. ОП. 1. Д. 5

8. Красноярский рабочий. 1938. 1 июня.

9. ГАКК. Ф. Р-1266. ОП. 1. Д. 12.

10. Красноярский рабочий. 1939. 18 мая.

11. Красноярский рабочий. 1939. 18 июля.

12. ГАКК. Ф. Р-1266. Оп. 1. Д. 4.

13. Красноярский рабочий. 1940. 27 мая.

14. ГАКК. Ф. Р-1266. Оп. 1. Д. 15.

15. ГАКК. Ф. Р-1266. ОП. 1. Д. 7.

16. ГАКК. Ф. Р-1736. Оп. 3. Д. 150

Статья представлена научной редакцией «История» 16 августа 2016 г.

\section{ACTIVITIES OF KRASNOYARSK LAW SCHOOL IN 1937-1938}

Vestnik Tomskogo gosudarstvennogo universiteta - Tomsk State University Journal, 2016, 411, 107-115. DOI: $10.17223 / 15617793 / 411 / 16$

Vladimir A. Pecherskiy, Khakassia Research Institute of Language, Literature and History (Abakan, Russian Federation). E-mail: volody75.75@mail.ru

Keywords: Krasnoyarsk Krai; Krasnoyarsk Law School; legal education in the USSR; judicial authorities.

The research aim is to study the activities of Krasnoyarsk Law School on training of justice personnel during the period from its establishment in 1937 to the start of the Great Patriotic War in 1941. The research is performed on the basis of the documents of the State Archive of Krasnoyarsk Krai, the majority of which have been introduced into scientific circulation for the first time. The author also uses academic monographs, articles and materials of periodicals. In the middle of the 1930s, the issue of training lawyers in the USSR was very acute. The majority of judges, prosecutors and investigators had no legal education. A network of law schools was established for accelerated training of justice personnel in the country. It was decided to open a law school in Krasnoyarsk in January 1937. The new School faced the problem of lack of a building that nearly led to the closure of the School by the decision of 
the People's Commissar of Justice of the RSFSR. This problem was resolved with a great difficulty, and the school continued its activities. At the end of the first academic year, 29 people graduated from the School. They were distributed to the judicial, prosecutor's, public defender's and notary's offices. Having trained the first group of specialists for authorities of justice of the region, the School started a new enrollment. On June 1, 1938 the newspaper Krasnoyarskiy Rabochiy published an announcement about enrollment to the School. The heads of the Regional Court and the Regional Prosecutor's Office also instructed people's judges and district prosecutors on the seconding of "persons from among the legal staff meeting the requirements of enrollment" to the School. The Regional Committee designated a certain number of positions for each district in the Law School and obligated regional party organizations to report on the implementation of this order. Classes in the 1938-1939 academic year began on September 1, 1938. The teaching staff consisted of teachers of the Russian language, mathematics, history of the USSR, history of the All-Union Communist Party of Bolsheviks, criminal law, criminal procedure, civil law, civil procedure, judicial system, criminology, labor law, medical jurisprudence and psychiatry. The Resolution of the Bureau of the Regional Committee requiring the chairperson of the Regional Court and the regional prosecutor to send teachers of legal subjects from among practitioners of the court and of the Prosecutor's Office helped to provide the school with the teaching staff. The scope of knowledge of law school graduates did not meet the needs of judicial authorities. The quality of graduates' work showed that after one academic year they were unable to master the entire volume of knowledge required to become sound professionals. To overcome these disadvantages it was necessary to increase the period of study. According to the order of the People's Commissar of Justice of the USSR as of May 11, 1939 "On the transfer of legal schools to a biennial training period" some applicants in 1939 were enlisted for a one-year training period and the others for a biennial period. In 1940 there was the last class of graduates that studied for one year; in 1941 the first class of students that studied for two years graduated. The author comes to a conclusion that Krasnoyarsk Law School gave a low level of education the causes of which were the poor qualification of teachers, a shortage of textbooks, a short training period and the weak educational preparation of students.

\section{REFERENCES}

1. Kodintsev, A.Ya. (2007) Srednee yuridicheskoe obrazovanie v sisteme organov yustitsii SSSR v 30-e gody XX veka [Vocational legal education in the USSR system of judicial authorities in the 1930s]. Srednee professional'noe obrazovanie. 9. pp. 83-84.

2. Kodintsev, A.Ya. (2007) Zaochnoe yuridicheskoe obrazovanie v sisteme organov yustitsii SSSR v 30-e gg. XX veka [Distance legal education in the USSR system of judicial authorities in the 1930s]. Nauchnye issledovaniya v obrazovanii. 6. pp. 74-79.

3. Solomon, P. (1998) Sovetskaya yustitsiya pri Staline [Soviet justice under Stalin]. Translated from English by L. Maksimenkov. Moscow: ROSSPEN.

4. State Archive of Krasnoyarsk Krai (GAKK). Fund R-1266. List 1. File 1. (In Russian).

5. Krasnoyarskiy rabochiy. (1937). 15 March.

6. State Archive of Krasnoyarsk Krai (GAKK). Fund R-1266. List 1. File 2. (In Russian).

7. State Archive of Krasnoyarsk Krai (GAKK). Fund R-1266. List 1. File 5. (In Russian).

8. Krasnoyarskiy rabochiy. (1938) 1 June.

9. State Archive of Krasnoyarsk Krai (GAKK). Fund R-1266. List 1. File 12. (In Russian).

10. Krasnoyarskiy rabochiy. (1939) 18 May.

11. Krasnoyarskiy rabochiy. (1939) 18 July.

12. State Archive of Krasnoyarsk Krai (GAKK). Fund R-1266. List 1. File 4. (In Russian).

13. Krasnoyarskiy rabochiy. (1940) 27 May.

14. State Archive of Krasnoyarsk Krai (GAKK). Fund R-1266. List 1. File 15. (In Russian).

15. State Archive of Krasnoyarsk Krai (GAKK). Fund R-1266. List 1. File 7. (In Russian).

16. State Archive of Krasnoyarsk Krai (GAKK). Fund R-1736. List 3. File 150. (In Russian). 